\title{
inorganics
}

ISSN 2304-6740

www.mdpi.com/journal/inorganics

Article

\section{Synthesis of $\mathrm{Ru}_{2} \mathrm{Br}\left(\mu-\mathrm{O}_{2} \mathrm{CC}_{6} \mathrm{H}_{4}-R\right)_{4}(R=o-\mathrm{Me}, m-\mathrm{Me}, p-\mathrm{Me})$ Using Microwave Activation: Structural and Magnetic Properties}

Patricia Delgado-Martínez ${ }^{1}$, Alejandra Elvira-Bravo ${ }^{1}$, Rodrigo González-Prieto ${ }^{1}$, José L. Priego $^{1{ }^{1} *}$, Reyes Jimenez-Aparicio ${ }^{1, *}$ and M. Rosario Torres ${ }^{2}$

1 Departamento de Química Inorgánica, Facultad de Ciencias Químicas, Universidad Complutense de Madrid, Ciudad Universitaria, E-28040 Madrid, Spain; E-Mails: patriciadelgado@ucm.es (P.D.-M.); aebravo@ucm.es (A.E.-B.); rgprieto@quim.ucm.es (R.G.-P.)

2 Centro de Asistencia a la Investigación de Rayos X, Facultad de Ciencias Químicas, Universidad Complutense de Madrid, Ciudad Universitaria, E-28040 Madrid, Spain; E-Mail: mrtorres@quim.ucm.es

* Authors to whom correspondence should be addressed; E-Mails: bermejo@quim.ucm.es (J.L.P.); reyesja@quim.ucm.es (R.J.-A.); Tel.: +34-913944344 (J.L.P.); +34-913944334 (R.J.-A.); Fax: +34-913944352 (J.L.P. \& R.J.-A.).

Received: 4 July 2014; in revised form: 8 August 2014 / Accepted: 20 August 2014 /

Published: 3 September 2014

Abstract: New bromidotetracarboxylatodiruthenium(II,III) compounds of the type $\left[\mathrm{Ru}_{2} \mathrm{Br}\left(\mu-\mathrm{O}_{2} \mathrm{CC}_{6} \mathrm{H}_{4}-R\right)_{4}\right]_{n}[R=o$-Me (1), $m$-Me (2), $p$-Me (3)] have been prepared using microwave-assisted methods. Syntheses by means of solvothermal and conventional activations have also been carried out to compare different preparation methods. The crystal structure determination of complexes $\mathbf{1}-\mathbf{3}$ is also described. All compounds display a typical carboxylate-bridged paddlewheel-type structure with the metal atoms connected by four bridging carboxylate ligands. The axial bromide ligands connect the dimetallic units giving one-dimensional zigzag chains. The magnetic properties of all compounds have also been analyzed. Weak antiferromagnetic intermolecular interactions mediated by the bromide ligands and an appreciable zero field splitting are calculated in the fits of the magnetic data of these complexes.

Keywords: diruthenium; microwave; one-dimensional; paddlewheel; magnetism; dinuclear 


\section{Introduction}

Since the publication of the first paper describing a quadruple bond between two metal atoms [1], whose 50th anniversary is being celebrated this year, 2014, the number of compounds containing metal-metal bonds has grown at an extraordinary rate [2,3]. The study of compounds with metal-metal bonds has been very important in the last 50 years, not only for furthering our understanding of the metal-metal bond, but also for the applications of this type of complexes in several fields $[2,3]$.

One of the most interesting types of compounds with metal-metal bonds is the dinuclear species called "paddlewheel" or "lantern" compounds. These complexes of formula $\left[M_{2} L_{4}\right]^{n+}(M=$ transition metal, $L=$ three atom bridging mononegative ligand, $n=0,1,2)$ are known for most of the transition metals [2,3]. In particular, the chloridotetracarboxylatodiruthenium(II,III) complexes have been extensively studied due to their interesting magnetic and electronic properties [2-5]. In these complexes the ruthenium atoms present formally two different oxidation states (2 and 3), although actually the averaged oxidation state is 2.5 . This fact is supported by a $\sigma^{2} \pi^{4} \delta^{2}\left(\pi^{*} \delta^{*}\right)^{3}$ electronic structure of the $\mathrm{Ru}_{2}{ }^{5+}$ unit, and therefore these compounds have a Ru-Ru bond order of 2.5 [2-6]. The potential uses of this type of ruthenium complexes as pharmaceutical agents, [7,8] and references in [7] as molecular materials and in nanochemistry, have led to a renewed interest [9-13]. In any case, the properties of chloro compounds $\left[\mathrm{Ru}_{2} \mathrm{Cl}\left(\mu-\mathrm{O}_{2} \mathrm{CR}\right)_{4}\right]$ are the most studied in the diruthenium chemistry, whereas the analogous bromo derivatives $\left[\mathrm{Ru}_{2} \mathrm{Br}\left(\mu-\mathrm{O}_{2} \mathrm{CR}\right)_{4}\right]$ have received less attention. The communication between the diruthenium units could be strongly dependent on the bridging halide ligand nature and, therefore, it is important to analyze the differences between chloride and bromide derivatives.

Chloridotetracarboxylatodiruthenium(II,III) complexes are usually obtained by the metathesis reaction of $\left[\mathrm{Ru}_{2} \mathrm{Cl}\left(\mu-\mathrm{O}_{2} \mathrm{CMe}\right)_{4}\right]$ with an excess of the corresponding carboxylic acid in a mixture of methanol/water at reflux for several hours [2-5]. In some cases, two metathesis cycles are necessary to ensure the complete replacement of the acetate ligand in $\left[\mathrm{Ru}_{2} \mathrm{Cl}\left(\mu-\mathrm{O}_{2} \mathrm{CMe}\right)_{4}\right]$. However, the use of microwave activation opens up the possibility to prepare dinuclear compounds in a substantially reduced time [14-22].

In fact, for dinuclear complexes, Johnson and Powel [14] noted that dimolybdenum tetracarboxylates could be obtained in less than $1 \mathrm{~h}$ using a microwave oven and a closed vessel. This procedure leads to better yields and shorter reaction times than the conventional ones. In addition, we have also recently shown that microwave activation is very useful in the preparation of dinuclear complexes of ruthenium [15-22].

In this paper we analyze the use of microwave activation for the preparation of three new bromidotetracarboxylatodiruthenium(II,III) derivatives $\left[\mathrm{Ru}_{2} \mathrm{Br}\left(\mu-\mathrm{O}_{2} \mathrm{CC}_{6} \mathrm{H}_{4}-R\right)_{4}\right]_{n}[R=o$-Me (1), $m-\mathrm{Me}$ (2), $p$-Me (3)]. We have chosen the $o$-, $m$ - and $p$-methylbenzoate ligands in order to study the influence of an aromatic ligand with the same substituent in different positions on the properties of these complexes. The preparation by solvothermal and conventional methods has been also carried out in order to compare different synthesis procedures. 


\section{Results and Discussion}

\subsection{Synthetic Aspects}

The reaction of $\left[\mathrm{Ru}_{2} \mathrm{Br}\left(\mu-\mathrm{O}_{2} \mathrm{CMe}\right)_{4}\right]$ with $o-, m$ - and $p$-toluic acid in deionised water was carried out in a TFM Teflon vessel placed in a microwave oven. After $16 \mathrm{~h}$ of activation at $130{ }^{\circ} \mathrm{C}$ the complexes $\left[\mathrm{Ru}_{2} \mathrm{Br}\left(\mu-\mathrm{O}_{2} \mathrm{CC}_{6} \mathrm{H}_{4}-R\right)_{4}\right]_{n}[R=o-\mathrm{Me}(\mathbf{1}), m-\mathrm{Me}(2), p$-Me (3) $]$ were obtained in $44 \%, 80 \%$ and $51 \%$ yield for 1, 2 and 3 respectively. Thus, using microwave activation and a green solvent, like water, the bromidotetracarboxylato derivatives 1-3 have been obtained from moderate to high yields. In order to compare these results with other preparation procedures, the use of solvothermal and conventional activation were also tested. Using solvothermal activation 1, 2 and 3 were obtained in 68\%, 59\% and 65\% yield respectively. Compounds 1-3 have been also prepared using the conventional metathesis reaction of $\left[\mathrm{Ru}_{2} \mathrm{Br}\left(\mu-\mathrm{O}_{2} \mathrm{CMe}\right)_{4}\right]$ with the corresponding $o$-, $m$ - and $p$-toluic acid in water/methanol mixture at reflux. By this procedure, complexes were obtained in $70 \%, 51 \%$ and $89 \%$ yield respectively. In all of the tested procedures, the yields range from moderate to high and there are no significant differences between them. Thus, the use of microwave activation in the preparation of $\mathbf{1}-\mathbf{3}$ does not improve the yield, in contrast with previous results reported for the successful application of microwave energy in the preparation of tetrakis(diaryltriazenido)diruthenium complexes $[15,16]$. These results also contrast with those observed in the microwave preparation of chloridotetracarboxylatodiruthenium compounds [17,18], which leads to better yields than the conventional methods. These differences are probably more related to the nature of the halide ions than to the used carboxylate ligand.

Complexes 1-3 are insoluble in most usual organic solvents, similarly to other halidotetraarylcarboxylatodiruthenium complexes. As has been previously observed in analogous complexes [15-22], in the case of compounds 1-3 the conventional and microwave preparation methods lead to microcrystalline solids, whereas the solvothermal reaction allows the obtention of larger single crystals for all of them.

\subsection{Crystal Structures}

The crystal structure determination of complexes 1-3 has been carried out. All of the complexes adopt the typical paddlewheel structure, with two ruthenium atoms supported by four bridging carboxylate ligands (Figures $1-3$ ). The cationic $\left[\mathrm{Ru}_{2}\left(\mu-\mathrm{O}_{2} \mathrm{CR}\right)_{4}\right]^{+}$units are bridged by bromide anions giving infinite zigzag chains $(-\mathrm{Ru}-\mathrm{Ru}-\mathrm{Br}-)_{n}$. Thus, each $\mathrm{Ru}$ atom shows a slightly distorted octahedral environment, with the four equatorial positions occupied by the oxygen atoms of the carboxylate ligands. The axial sites are occupied by a bromide ligand and by the other $\mathrm{Ru}$ atom from the same dimetallic unit. The Ru-Ru bond lengths are 2.2938(5) $\AA$ for 1, 2.2885(8) and 2.2893(8) $\AA$ for 2 and 2.2898(7) $\AA$ for 3. These distances are very similar to those found in analogous chloridocarboxylates $\left[\mathrm{Ru}_{2} \mathrm{Cl}\left(\mu-\mathrm{O}_{2} \mathrm{CR}\right)_{4}\right]$ (Table 1) [17] and in other carboxylatodiruthenium complexes containing the $\mathrm{Ru}_{2}{ }^{5+}$ unit [2-5]. The $\mathrm{Ru}-\mathrm{Br}$ distances range from 2.6630(5) to 2.7030(7) $\AA$ (Table 1) and are similar to those found in bromidocarboxylates $\left[\mathrm{Ru}_{2} \mathrm{Br}\left(\mu-\mathrm{O}_{2} \mathrm{CH}\right)_{4}\right] \quad(2.7170(8)$ and 2.7313(9) $\AA)$ [23], $\left[\mathrm{Ru}_{2} \mathrm{Br}\left(\mu-\mathrm{O}_{2} \mathrm{CEt}\right)_{4}\right](2.7101 \AA)[11]$ and $\left[\mathrm{Ru}_{2} \mathrm{Br}\left(\mu-\mathrm{O}_{2} \mathrm{CPh}\right)_{4}\right]$ (2.6700(5) $\left.\AA\right),\left[\mathrm{Ru}_{2} \mathrm{Br}\left(\mu-\mathrm{O}_{2} \mathrm{CC}_{6} \mathrm{H}_{4}-p-\right.\right.$ $\left.\mathrm{OMe})_{4}\left(\mathrm{H}_{2} \mathrm{O}\right)\right] \cdot \mathrm{H}_{2} \mathrm{O}(2.671(2) \AA),\left[\mathrm{Ru}_{2} \mathrm{Br}\left(\mu-\mathrm{O}_{2} \mathrm{CCMePh}_{2}\right)_{4}(\mathrm{EtOH}) \cdot 0.5 \mathrm{EtOH}\right](2.6108(17) \AA)$ [24]. The 
analogous bromidotetraamidate complexes $\left[\mathrm{Ru}_{2} \mathrm{Br}\left(\mu-\mathrm{NHOCC}_{6} \mathrm{H}_{4}-R\right)_{4}\right]_{n}(R=o-\mathrm{Me}, m-\mathrm{Me}, p$-Me $)$ also show similar $\mathrm{Ru}-\mathrm{Br}$ distances: from 2.6655(7) to 2.728(2) $\AA$ [18]. The $\mathrm{Ru}-\mathrm{Br}-\mathrm{Ru}$ angle in $\mathbf{1}-\mathbf{3}$ is very similar, ranging from $116.36(2)^{\circ}$ to $116.56(2)^{\circ}$. In the solid state, the one dimensional zigzag chains are packed only by van der Waals forces.

Figure 1. Left: thermal-ellipsoid representation of the paddlewheel monomer of complex 1 (50\% probability ellipsoids); Right: zigzag chain. Hydrogen atoms are omitted in both cases for clarity.

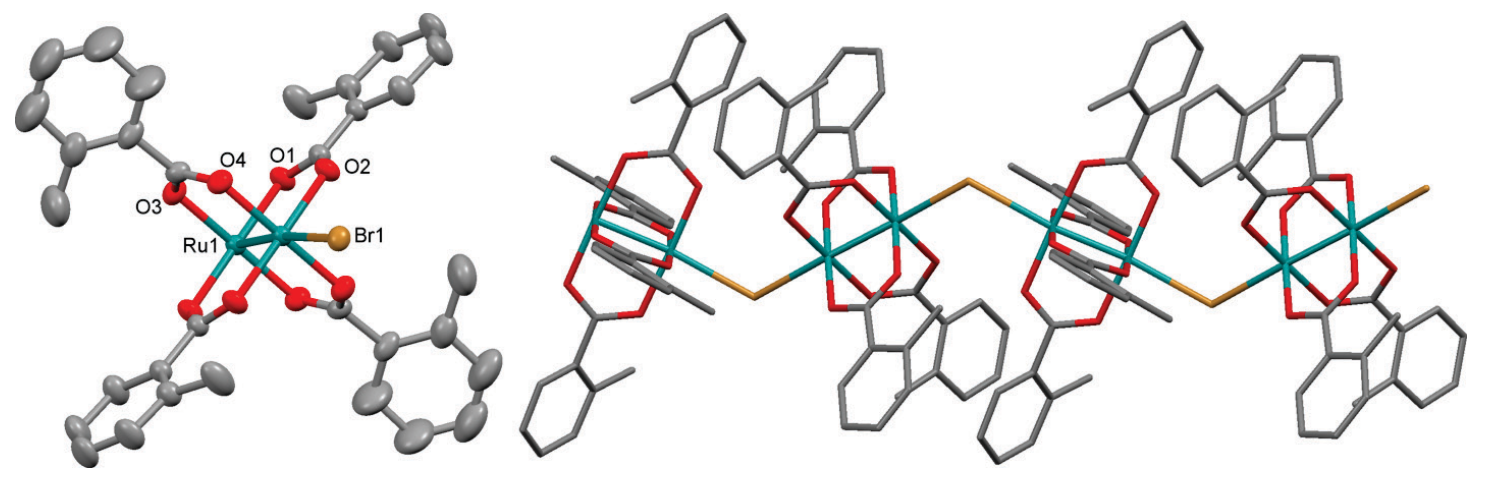

Figure 2. Left: thermal-ellipsoid representation of the one paddlewheel unit of complex 2 (50\% probability ellipsoids); Right: zigzag chain. Hydrogen atoms are omitted in both cases for clarity.
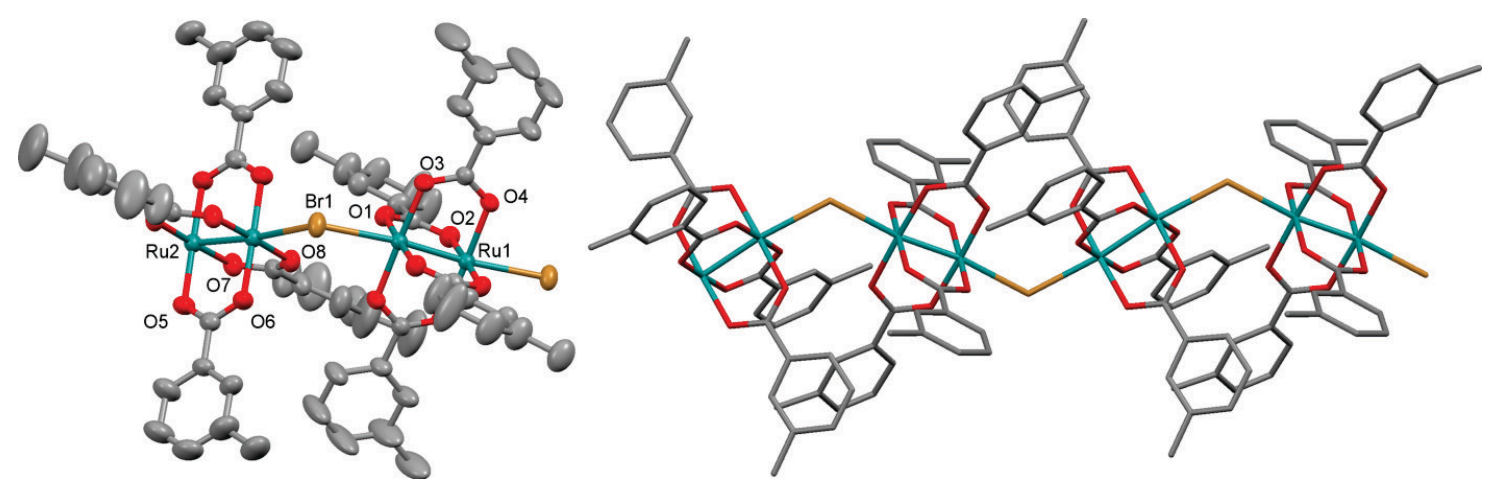

Figure 3. Left: thermal-ellipsoid representation of two paddlewheel units of $3(50 \%$ probability ellipsoids); Right: packing of zigzag chains. Hydrogen atoms are omitted in both cases for clarity.

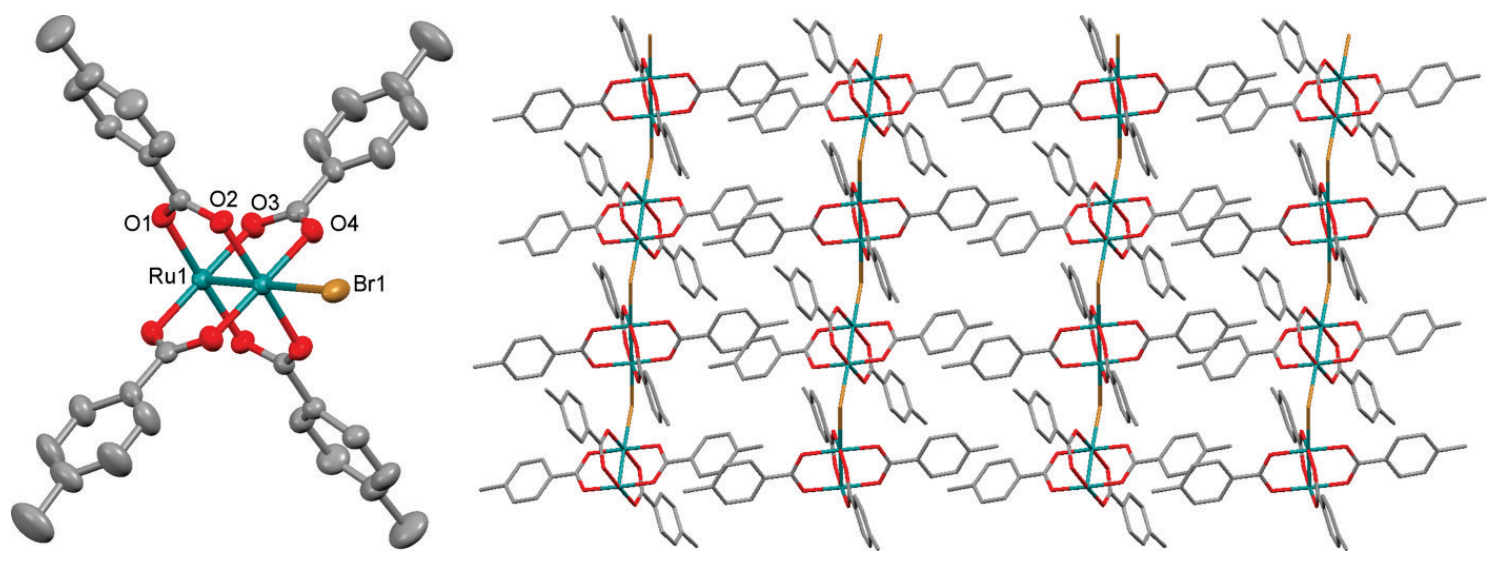


Table 1. Bond distances and angles in compounds 1-3 and in the carboxylate compounds $\left[\mathrm{Ru}_{2} \mathrm{Cl}\left(\mu-\mathrm{O}_{2} \mathrm{CC}_{6} \mathrm{H}_{4}-R\right)_{4}\right]_{n}(R=o-\mathrm{Me}, m-\mathrm{Me}, p-\mathrm{Me})$.

\begin{tabular}{|c|c|c|c|c|}
\hline Compound & $\mathbf{R u}-\mathbf{R u} / \mathbf{A}$ & $\mathbf{R u}-X / \AA$ & $\mathbf{R u}-X-\mathbf{R u} /^{\circ}$ & $\theta$ angle $/{ }^{\circ}$ \\
\hline$\left[\mathrm{Ru}_{2} \mathrm{Br}\left(\mu-\mathrm{O}_{2} \mathrm{CC}_{6} \mathrm{H}_{4}-\mathrm{o}-\mathrm{CH}_{3}\right)_{4}\right]_{n}(1)$ & $2.2938(5)$ & $2.6910(4)$ & $116.36(2)$ & $\begin{array}{c}48.89 \\
9.52\end{array}$ \\
\hline$\left[\mathrm{Ru}_{2} \mathrm{Br}\left(\mu-\mathrm{O}_{2} \mathrm{CC}_{6} \mathrm{H}_{4}-m-\mathrm{CH}_{3}\right)_{4}\right]_{n}(2)$ & $\begin{array}{l}2.2885(8) \\
2.2893(8)\end{array}$ & $\begin{array}{l}2.6815(7) \\
2.7030(7)\end{array}$ & $116.56(2)$ & $\begin{array}{c}8.26 \\
4.35 \\
24.79 \\
3.92\end{array}$ \\
\hline$\left[\mathrm{Ru}_{2} \mathrm{Br}\left(\mu-\mathrm{O}_{2} \mathrm{CC}_{6} \mathrm{H}_{4}-p-\mathrm{CH}_{3}\right)_{4}\right]_{n}(3)$ & $2.2898(7)$ & $2.6630(5)$ & $116.51(3)$ & $\begin{array}{c}10.58 \\
5.78\end{array}$ \\
\hline$\left[\mathrm{Ru}_{2} \mathrm{Cl}\left(\mu-\mathrm{O}_{2} \mathrm{CC}_{6} \mathrm{H}_{4}-\sigma-\mathrm{CH}_{3}\right)_{4}\right]_{n}{ }^{\mathrm{a}}$ & $2.2875(3)$ & $2.5590(4)$ & $121.45(3)$ & $\begin{array}{l}51.13 \\
11.47\end{array}$ \\
\hline$\left[\mathrm{Ru}_{2} \mathrm{Cl}\left(\mu-\mathrm{O}_{2} \mathrm{CC}_{6} \mathrm{H}_{4}-m-\mathrm{CH}_{3}\right)_{4}\right]_{n}{ }^{\mathrm{a}}$ & $\begin{array}{l}2.295(2) \\
2.283(3)\end{array}$ & $\begin{array}{l}2.585(4) \\
2.565(4)\end{array}$ & $118.8(2)$ & $\begin{array}{c}9.99 \\
5.45 \\
28.13 \\
3.47 \\
\end{array}$ \\
\hline$\left[\mathrm{Ru}_{2} \mathrm{Cl}\left(\mu-\mathrm{O}_{2} \mathrm{CC}_{6} \mathrm{H}_{4}-p-\mathrm{CH}_{3}\right)_{4}\right]_{n}{ }^{\mathrm{a}}$ & $2.2906(5)$ & $2.5400(6)$ & $118.88(4)$ & $\begin{array}{c}10.43 \\
4.73\end{array}$ \\
\hline
\end{tabular}

${ }^{\mathrm{a}}$ Reference [17].

The main structural parameters of complexes 1-3 are analogous, showing a slight variation in function of the position of the methyl group. The main difference is found in the dihedral angle, $\theta$, defined by the plane occupied by the carboxylate group and the ruthenium atoms and the plane defined by the phenyl ring (Table 1). In each paddlewheel unit of each complex two $\theta$ angles can be found, showing a different orientation of the phenyl rings located in cis. The methyl group in the ortho position in complex 1 forces the greatest rotation of the aromatic rings: $48.89^{\circ}$ and $9.52^{\circ}$, being lower in 2 and 3 (Table 1). A very similar rotation $\theta$ angle is found in the analogous chloro derivatives $\left[\mathrm{Ru}_{2} \mathrm{Cl}\left(\mu-\mathrm{O}_{2} \mathrm{CC}_{6} \mathrm{H}_{4}-\mathrm{R}\right)_{4}\right]_{n}$ (Table 1). It is noteworthy that the presence of the methyl group in the ortho, meta or para positions of the aromatic ring does not have any influence in the $\mathrm{Ru}-\mathrm{Br}-\mathrm{Ru}$ angle for the bromo derivatives. This result contrast with those observed in the chloro compound $\left.\mathrm{Ru}_{2} \mathrm{Cl}\left(\mu-\mathrm{NHOCC}_{6} \mathrm{H}_{4}-o-\mathrm{Me}\right)_{4}\right]_{n}$ in which the ortho complex show a $\mathrm{Ru}-\mathrm{Cl}-\mathrm{Ru}$ angle of $180^{\circ}$ [17].

To be sure that each sample contains only a single phase, the PXRD diffractograms simulated from the X-ray single crystal determination and the PXRD experimental measurements of the bulk samples were compared. As can be observed in the Supplementary File (Figures S1-S3), both diffractograms for each sample agree well.

\subsection{Spectroscopic Properties}

The IR spectra of compounds 1-3 (Figures S4-S6, Supplementary Information) show very strong antisymmetric and symmetric stretching COO bands $\left(1466-1376 \mathrm{~cm}^{-1}\right)$ due to the bridging equatorial carboxylate ligands. The pattern of all spectra is very similar, suggesting the same basic unit of two ruthenium atoms supported by four bridging carboxylate ligands. Characteristic bands of the toluic groups are also observed. The $\mathrm{C}-\mathrm{C}$ stretching bands of the phenyl group appear in the range 
1608-1494 $\mathrm{cm}^{-1}$ and weak bands corresponding to the methyl group are observed between 2973 and $2912 \mathrm{~cm}^{-1}$. No appreciable differences in the IR spectra of each compound have been observed for the different synthesis procedures used.

The diffuse reflectance spectra of all complexes show only three well defined bands: (i) the absorption band observed in the range $344-350 \mathrm{~nm}$, which could be assigned to a ligand-metal charge-transfer $\sigma$ (axial ligand) $\rightarrow \sigma^{*}\left(\mathrm{Ru}_{2}\right)$ transition, in agreement with those described for other diruthenium compounds [25-27]; (ii) the band observed between 479 and $492 \mathrm{~nm}$, which is attributed to the $\pi\left(\mathrm{Ru}-\mathrm{O}, \mathrm{Ru}_{2}\right) \rightarrow \pi^{*}\left(\mathrm{Ru}_{2}\right)$ transition [17,24,28,29], although it could also have some $\sigma \rightarrow \sigma^{*}$ character [25-27]; (iii) the band found in the NIR region in the range 1128-1168 nm, which can be assigned to the $\delta\left(\mathrm{Ru}_{2}\right) \rightarrow \delta^{*}\left(\mathrm{Ru}_{2}\right)$ transition [17,24-30]. Table 2 collects the electronic data of complexes 1-3 and Figure S7 shows the corresponding curves in the Supplementary Infoprmation. The electronic spectrum of each compound is independent of the used synthetic procedure.

Table 2. Electronic spectra data (nm) for compounds 1-3.

\begin{tabular}{cccc}
\hline Compound & $\boldsymbol{\sigma}($ Axial ligand $) \rightarrow \boldsymbol{\sigma}^{*}\left(\mathbf{R} \mathbf{u}_{\mathbf{2}}\right)$ & $\boldsymbol{\pi}\left(\mathbf{R u}-\mathbf{O}, \mathbf{R} \mathbf{u}_{\mathbf{2}}\right) \rightarrow \boldsymbol{\pi}^{*}\left(\mathbf{R} \mathbf{u}_{\mathbf{2}}\right)$ & $\boldsymbol{\delta}\left(\mathbf{R} \mathbf{u}_{\mathbf{2}}\right) \rightarrow \boldsymbol{\delta} *\left(\mathbf{R} \mathbf{u}_{\mathbf{2}}\right)$ \\
\hline $\mathbf{1}$ & 344 & 479 & 1128 \\
$\mathbf{2}$ & 349 & 486 & 1153 \\
$\mathbf{3}$ & 350 & 492 & 1168 \\
\hline
\end{tabular}

\subsection{Magnetic Properties}

Magnetic measurements at variable temperature of compounds 1-3 show magnetic moments at room temperature in the range 4.20-4.50 $\mu_{\mathrm{B}}$ (Table 3 ), similar to those found in other tetracarboxylatodirutenium(II,III) compounds [2-5]. These values are in accordance with the ground-state configuration $\sigma^{2} \pi^{4} \delta^{2}\left(\pi^{*} \delta^{*}\right)^{3}$, proposed by Norman et al. [6], which indicates the presence of three unpaired electrons per diruthenium unit. The representation of the magnetic moment versus temperature shows a continuous decrease, which becomes more pronounced at very low temperatures, whereas the molar susceptibility increases continuously. This behavior is typical of similar zigzag polymeric diruthenium(II,III) tetracarboxylates, and is ascribed to a large zero-field splitting $(D)$ and a weak degree of antiferromagnetic coupling $(z J)$ between the $\mathrm{Ru}_{2}{ }^{5+}$ units. The model of Cukiernick et al. [31] has been used previously to fit the magnetic data in similar diruthenium(II,III) compounds [2-5,17,18]. This model takes into account the existence of $D$ and $z J$, but also a temperature independent paramagnetism $(T I P)$ and a paramagnetic impurity $(P)$ of a mononuclear complex of $\mathrm{Ru}(\mathrm{III})$ with $\mathrm{S}=1 / 2$, as is usual in similar fits (See the equations in Supplementary File). This model permits to successfully fit the magnetic data of compounds 1-3. A very good agreement between the experimental and calculated curves of the magnetic moment and the molar susceptibility for complexes 1-3 is observed. Figure 4 shows the experimental and calculated curves using this model for complex 1. Similar fits are obtained for complexes 2 and 3 (Figure S8 and S9, Supplementary Information). The calculated magnetic parameters $(g, D, z J, T I P$ and $P$ ) obtained in these fits are collected in Table 3 together with the $\sigma^{2}$ value, which indicates the quality of the fits. The large zero-field splitting calculated values $\left(D=49.22-51.77 \mathrm{~cm}^{-1}\right)$ are similar to those found for analogous compounds $[2-5,17,18,31-33]$. The calculated $z J$ antiferromagnetic coupling constants vary 
from -0.73 to $-2.76 \mathrm{~cm}^{-1}$. These low values are consistent with a polymeric structure based in zigzag chains $[4,5,17,18,31-33]$, where the interchange antiferromagnetic interaction is propagated through the bridging bromide ligands.

Table 3. Magnetic parameters obtained in the fits of the magnetic moment as a function of temperature for compounds $\mathbf{1}-\mathbf{3}$.

\begin{tabular}{cccccccc}
\hline Compound & $\boldsymbol{\mu}_{\text {eff. }}\left(\mathbf{r t}, \boldsymbol{\mu}_{\mathbf{B}}\right)$ & $\boldsymbol{g}$ & $\boldsymbol{D}\left(\mathbf{c m}^{-\mathbf{1}}\right)$ & $\boldsymbol{z} \boldsymbol{J}\left(\mathbf{c m}^{-\mathbf{1}}\right)$ & $\mathbf{T I P}(\mathbf{m L} / \mathbf{m o l})$ & $\boldsymbol{P}(\mathbf{\%})$ & $\boldsymbol{\sigma}^{\mathbf{2}}$ \\
\hline $\mathbf{1}$ & 4.39 & 2.12 & 49.22 & -2.60 & $1.42 \times 10^{-3}$ & 0.01 & $1.45 \times 10^{-5}$ \\
$\mathbf{2}$ & 4.50 & 2.09 & 51.77 & -0.73 & $1.81 \times 10^{-3}$ & $1.02 \times 10^{-4}$ & $1.99 \times 10^{-5}$ \\
$\mathbf{3}$ & 4.20 & 2.13 & 51.09 & -2.76 & $3.68 \times 10^{-4}$ & 0.64 & $3.33 \times 10^{-5}$ \\
\hline
\end{tabular}

Figure 4. Temperature dependence of the molar susceptibility $\chi_{M}(\circ)$ and $\mu_{\text {eff. }}(\Delta)$ for complex 1; solid lines are the product of a least-squares fit to the model indicated in the text.

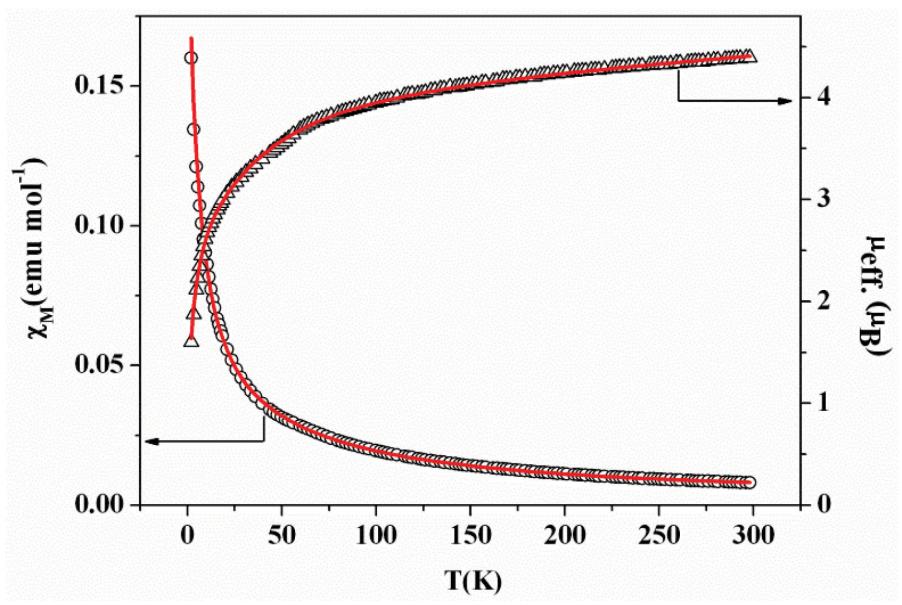

\section{Experimental Section}

\subsection{General Considerations}

All reactants and solvents were used as received. The precursors $\left[\mathrm{Ru}_{2} \mathrm{Cl}\left(\mu-\mathrm{O}_{2} \mathrm{CMe}\right)_{4}\right]$ and $\left[\mathrm{Ru}_{2} \mathrm{Br}\left(\mu-\mathrm{O}_{2} \mathrm{CMe}\right)_{4}\right]$ were synthesized according to published general procedures [34,35]. Microwave reactions were carried out in an ETHOS ONE (Shelton, CT, USA) microwave oven using TFM (Shelton, CT, USA ) Teflon closed vessels equipped with a temperature sensor and pressure control. Solvothermal synthesis was carried out in a Memmert (Schwabach, Germany) Universal Oven UFE 400 using Teflon-lined stainless steel autoclaves. Elemental analyses were done by the Microanalytical Service of the Universidad Complutense de Madrid. FT-IR spectra were recorded in a Perkin Elmer (Waltham, MA, USA) Spectrum 100 with a universal ATR accessory in the range 4000-650 $\mathrm{cm}^{-1}$. Magnetization measurements at variable temperature were obtained with a Quantum Design MPMSXL SQUID (San Diego, CA, USA) (Superconducting Quantum Interference Device) magnetometer over a temperature range of $2-300 \mathrm{~K}$ at the constant field of $1 \mathrm{~T}$. Molar susceptibility values calculated from magnetization data were corrected for the diamagnetic contribution of both the sample holder and the compound to the susceptibility. The molar diamagnetic corrections for the complexes were calculated on the basis of Pascal's constants. As impurities even in low concentrations 
can affect the magnetic results, crushed crystals were used in the magnetic measurements to ensure the homogeneity of the sample. Electronic spectra of the complexes in the solid state were acquired on a Cary (Santa Clara, CA, USA) 5 G spectrophotometer equipped with a Praying Mantis (Santa Clara, CA, USA) accessory for diffuse reflectance measurements. The reflectance data were converted by the instruments software (Santa Clara, CA, USA) to the $F(\mathrm{R} \infty)$ values according to the Kubelka-Munk theory. Powder X-ray diffraction (PXRD) measurements were done on an X'Pert (Almelo, The Netherlands) PRO ALPHA1 diffractometer with $\theta / 2 \theta$ configuration. Rietveld refinements were carried out using X'pert High Score Plus software (Almelo, The Netherlands) in automatic mode.

\subsection{X-ray Data Collection and Structure Refinement}

Data collection was carried out at room temperature on a Bruker Smart (Bremen, Germany) CCD diffractometer for $\mathbf{1}$ and on a Xcalibur (Santa Clara, CA, USA), Atlas CCD diffractometer for 2 and 3. In all cases, graphite-monochromated Mo-K $\alpha$ radiation $(\lambda=0.71073 \AA)$ operating at $50 \mathrm{kV}$ and $35 \mathrm{~mA}$ for $\mathbf{1}$ and at $50 \mathrm{kV}$ and $40 \mathrm{~mA}$ for $\mathbf{2}$ and $\mathbf{3}$ was used. The exposure times were $20 \mathrm{~s}$ for $\mathbf{1}$ and $11.1 \mathrm{~s}$, and $3.34 \mathrm{~s}$ for $\mathbf{2}$ and $\mathbf{3}$.

A summary of the fundamental crystal and refinement data is given in Table 4 .

Table 4. Crystallographic data for 1-3.

\begin{tabular}{|c|c|c|c|}
\hline Crystal Data & 1 & 2 & 3 \\
\hline Empirical formula & $\mathrm{C}_{32} \mathrm{H}_{28} \mathrm{BrO}_{8} \mathrm{Ru}_{2}$ & $\mathrm{C}_{32} \mathrm{H}_{28} \mathrm{BrO}_{8} \mathrm{Ru}_{2}$ & $\mathrm{C}_{32} \mathrm{H}_{28} \mathrm{BrO}_{8} \mathrm{Ru}_{2}$ \\
\hline Formula wt & 822.59 & 822.59 & 822.59 \\
\hline Diffractometer & Bruker, CCD area detector & Oxford, Xcalibur ${ }^{\mathrm{TM}} \mathrm{A}$ & Oxford, Xcalibur ${ }^{\mathrm{TM}} \mathrm{A}$ \\
\hline Scan method & Phi and Omega & Omega & Omega \\
\hline Radiation & $\operatorname{MoK} \alpha(0.71073 \AA)$ & $\operatorname{MoK}(0.71073 \AA)$ & $\operatorname{MoK}(0.71073 \AA \AA)$ \\
\hline Crystal system & Monoclinic & Monoclinic & Monoclinic \\
\hline Space group & $C 2 / c$ & $P 2_{1} / c$ & $I 2 / a$ \\
\hline$a / \AA$ & $18.773(1)$ & $13.0936(4)$ & $12.9939(7)$ \\
\hline$b / \AA$ & $13.5213(9)$ & $11.1271(4)$ & $10.1996(5)$ \\
\hline$c / \AA$ & $13.1634(8)$ & $21.8306(7)$ & $24.830(2)$ \\
\hline$\alpha /{ }^{\circ}$ & 90 & 90 & 90 \\
\hline$\beta /{ }^{\circ}$ & $109.159(1)$ & $98.071(3)$ & $94.623(5)$ \\
\hline$\gamma /{ }^{\circ}$ & 90 & 90 & 90 \\
\hline$V / \AA^{3}$ & $3156.3(3)$ & $3149.1(2)$ & $3280.0(3)$ \\
\hline $\mathrm{Z}$ & 4 & 4 & 4 \\
\hline$\rho_{\mathrm{c}} / \mathrm{g} / \mathrm{cm}^{3}$ & 1.731 & 1.735 & 1.666 \\
\hline$\mu(\mathrm{Mo}-\mathrm{K} \alpha) / \mathrm{mm}^{-1}$ & 2.272 & 2.277 & 2.186 \\
\hline $\mathrm{F}(000)$ & 1628 & 1628 & 1628 \\
\hline Crystal size $/ \mathrm{mm}^{3}$ & $0.33 \times 0.10 \times 0.06$ & $0.38 \times 0.16 \times 0.07$ & $0.50 \times 0.09 \times 0.07$ \\
\hline$\theta$ range $/^{\circ}$ & 1.89 to 26.00 & 3.37 to 26.00 & 3.43 to 26.00 \\
\hline Index ranges & $\begin{array}{l}-23,-14,-16 \text { to } \\
23,16,16\end{array}$ & $\begin{array}{l}-15,-13,-26 \text { to } \\
16,13,24\end{array}$ & $\begin{array}{l}-15,-12,-24 \text { to } \\
16,12,30\end{array}$ \\
\hline Reflections collected & 12858 & 15156 & 8036 \\
\hline Unique reflections & 3096 & 6181 & 3217 \\
\hline$\left[R_{\mathrm{int}}\right]$ & {$\left[R_{\mathrm{int}}=0.0440\right]$} & {$\left[R_{\mathrm{int}}=0.0399\right]$} & {$\left[R_{\mathrm{int}}=0.0454\right]$} \\
\hline
\end{tabular}


Table 4. Cont.

\begin{tabular}{|c|c|c|c|}
\hline Crystal Data & 1 & 2 & 3 \\
\hline Completeness to theta & $99.4 \%$ & $99.8 \%$ & $99.8 \%$ \\
\hline Absorption correction & $\begin{array}{l}\text { Semi-empirical from } \\
\text { equivalents }\end{array}$ & $\begin{array}{l}\text { Semi-empirical from } \\
\text { equivalents }\end{array}$ & $\begin{array}{l}\text { Semi-empirical from } \\
\text { equivalents }\end{array}$ \\
\hline Data/restraints/parameters & 3096/0/183 & $6181 / 0 / 364$ & $3217 / 0 / 195$ \\
\hline $\mathrm{H}$-atom treatment & $\begin{array}{l}\text { Calculated positions and } \\
\text { refined HFIX }\end{array}$ & $\begin{array}{l}\text { Calculated positions } \\
\text { and refined HFIX }\end{array}$ & $\begin{array}{l}\text { Calculated positions } \\
\text { and refined HFIX }\end{array}$ \\
\hline Goodness-of-fit on $\mathrm{F}^{2}$ & 0.995 & 0.993 & 0.997 \\
\hline$R_{1}\left(\right.$ reflns obsd) $[I>2 \sigma(I)]^{\mathrm{a}}$ & $0.0263(2492)$ & $0.0445(4452)$ & $0.0406(2290)$ \\
\hline$w R_{2}$ (all data) ${ }^{\mathrm{b}}$ & 0.0572 & 0.1206 & 0.0851 \\
\hline Largest diff. peak and hole/e. $\AA^{-3}$ & 0.560 and -0.469 & 0.954 and -0.909 & 0.700 and -0.497 \\
\hline
\end{tabular}

$$
{ }^{\mathrm{a}} R_{1}=\Sigma|| F_{\mathrm{o}}|-| F_{\mathrm{c}}|/ \Sigma| F_{\mathrm{o}} \mid{ }^{\mathrm{b}} w R_{2}=\left\{\Sigma\left[w\left(F_{\mathrm{o}}^{2}-F_{\mathrm{c}}{ }^{2}\right] / \Sigma\left[w\left(F_{\mathrm{o}}{ }^{2}\right)^{2}\right]\right\} .\right.
$$

The structures were solved by direct methods and refined by full-matrix least-squares procedures on $\mathrm{F}^{2}$ (SHELXL-97) [36].

All non-hydrogen atoms were refined anisotropically. All hydrogen atoms were included in their calculated positions and refined riding on the respective carbon atoms.

CCDC 1010423-1010425 contains the supplementary crystallographic data of complexes 1-3. These data can be obtained free of charge from The Cambridge Crystallographic Data Centre [37].

\subsection{Synthesis}

Synthesis of $\left[\mathrm{Ru}_{2} \mathrm{Br}\left(\mu-\mathrm{O}_{2} \mathrm{CC}_{6} \mathrm{H}_{4}-o-\mathrm{Me}\right)_{4}\right], \mathbf{1}$. This compound was prepared by the following methods:

Method (a): Microwave assisted synthesis. A $85 \mathrm{~mL}$ TFM Teflon vessel with magnetic stirrer bar was loaded with $\left[\mathrm{Ru}_{2} \mathrm{Br}\left(\mu-\mathrm{O}_{2} \mathrm{CMe}\right)_{4}\right](0.13 \mathrm{~g}, 0.25 \mathrm{mmol})$, o-toluic acid $(0.20 \mathrm{~g}, 1.5 \mathrm{mmol})$ and deionised water $(8 \mathrm{~mL})$. The vessel was sealed with a lid equipped with temperature and pressure sensors, and placed in the microwave oven. Reaction mixture was then treated by a three-step program consisting of: (i) a 15 min heating ramp up to $130{ }^{\circ} \mathrm{C}$; (ii) a $16 \mathrm{~h}$ isotherm at $130{ }^{\circ} \mathrm{C}$; and (iii) a $20 \mathrm{~min}$ cooling ramp down to room temperature. A brown suspension was obtained. The solid is filtered and washed twice with $10 \mathrm{~mL}$ of cold ethanol. Yield: $44 \%$. Anal. Calcd. (\%) for $\left[\mathrm{Ru}_{2} \mathrm{Br}\left(\mu-\mathrm{O}_{2} \mathrm{CC}_{6} \mathrm{H}_{4}-O-\mathrm{Me}\right)_{4}\right]$, $\mathrm{C}_{32} \mathrm{H}_{28} \mathrm{O}_{8} \mathrm{BrRu}_{2}$ : C, 46.72; H, 3.43. Found (\%): C, 46.51; H, 3.41.

Method (b): Solvothermal synthesis. Except for $\mathrm{MeOH}$, used in this case as a solvent, the same reagents and quantities used in method (a) were added to a $23 \mathrm{~mL}$ Teflon-lined autoclave and stirred several minutes to homogenize the reaction mixture. Reactor was closed and heated under a three-step program consisting of: (i) a $2 \mathrm{~h}$ heating ramp up to $130{ }^{\circ} \mathrm{C}$; (ii) a $24 \mathrm{~h}$ isotherm at $130{ }^{\circ} \mathrm{C}$; and (iii) a $24 \mathrm{~h}$ cooling ramp down to room temperature. The microcrystalline brown solid obtained was filtered and washed with cold ethanol $(5 \times 10 \mathrm{~mL})$. Yield: $68 \%$. Anal. Calcd. $(\%)$ for $\left[\operatorname{Ru}_{2} \operatorname{Br}(\mu-\right.$ $\left.\left.\mathrm{O}_{2} \mathrm{CC}_{6} \mathrm{H}_{4}-\mathrm{O}-\mathrm{Me}\right)_{4}\right] \cdot 1.5 \mathrm{H}_{2} \mathrm{O}, \mathrm{C}_{32} \mathrm{H}_{31} \mathrm{O}_{9.5} \mathrm{BrRu}_{2}$ : C, 45.24; H, 3.68. Found (\%): C, 45.14; H, 3.32.

Method (c): Conventional synthesis. $0.20 \mathrm{~g}$ of $o$-toluic acid $(1.5 \mathrm{mmol})$ were added to a suspension of bromidotetrakis(acetato)diruthenium(II,III) $(0.13 \mathrm{~g}, 0.25 \mathrm{mmol})$ in $30 \mathrm{~mL}$ of $\mathrm{MeOH} / \mathrm{H}_{2} \mathrm{O}$. Reaction mixture was refluxed for $4 \mathrm{~h}$, giving a brown precipitate. The solvent was removed by filtration and the 
brown solid washed twice with $10 \mathrm{~mL}$ of absolute ethanol. Yield: 70\%. Anal. Calcd. (\%) for $\left[\mathrm{Ru}_{2} \mathrm{Br}\left(\mu-\mathrm{O}_{2} \mathrm{CC}_{6} \mathrm{H}_{4}-O-\mathrm{Me}\right)_{4}\right] \cdot \mathrm{H}_{2} \mathrm{O}, \mathrm{C}_{32} \mathrm{H}_{30} \mathrm{O}_{9} \mathrm{BrRu}_{2}: \mathrm{C}, 45.72 ; \mathrm{H}, 3.60$. Found (\%): C, 45.82; H, 3.37.

IR $\left(\mathrm{cm}^{-1}\right): 2972 \mathrm{w}, 2927 \mathrm{w}, 1603 \mathrm{w}, 1570 \mathrm{w}, 1497 \mathrm{w}, 1462 \mathrm{~m}, 1441 \mathrm{~s}, 1386 \mathrm{~s}, 1290 \mathrm{~m}, 1194 \mathrm{w}, 1153 \mathrm{~m}$, $1104 \mathrm{~m}, 1052 \mathrm{w}, 1032 \mathrm{w}, 948 \mathrm{w}, 856 \mathrm{~m}, 788 \mathrm{~m}, 750 \mathrm{~m}, 740 \mathrm{~s}, 670 \mathrm{~s}$.

$$
\mu_{\mathrm{eff}}(\mathrm{rt})=4.39 \mu_{\mathrm{B}}
$$

Synthesis of $\left[\mathrm{Ru}_{2} \mathrm{Br}\left(\mu-\mathrm{O}_{2} \mathrm{CC}_{6} \mathrm{H}_{4}-m-\mathrm{Me}\right)_{4}\right]$, 2. This compound was obtained using the same synthetic methods described for 1 , with $m$-toluic acid $(0.20 \mathrm{~g}, 1.5 \mathrm{mmol})$.

Method (a): Yield: $80 \%$. Anal. Calcd. (\%) for $\left[\mathrm{Ru}_{2} \mathrm{Br}\left(\mu-\mathrm{O}_{2} \mathrm{CC}_{6} \mathrm{H}_{4}-m-\mathrm{Me}\right)_{4}\right], \mathrm{C}_{32} \mathrm{H}_{28} \mathrm{O}_{8} \mathrm{BrRu}_{2}$ : C, 46.72; H, 3.43. Found (\%): C, 46.56; H, 3.43.

Method (b): Yield: 59\%. Anal. Calcd. (\%) for $\left[\mathrm{Ru}_{2} \mathrm{Br}\left(\mu-\mathrm{O}_{2} \mathrm{CC}_{6} \mathrm{H}_{4}-m-\mathrm{Me}\right)_{4}\right] \cdot 2 \mathrm{H}_{2} \mathrm{O}, \mathrm{C}_{32} \mathrm{H}_{32} \mathrm{O}_{10} \mathrm{BrRu}_{2}$ : C, 44.76; H, 3.76. Found (\%): C, 44.73; H, 3.32.

Method (c): Yield: 51\%. Anal. Calcd. (\%) for $\left[\mathrm{Ru}_{2} \mathrm{Br}\left(\mu-\mathrm{O}_{2} \mathrm{CC}_{6} \mathrm{H}_{4}-m-\mathrm{Me}\right)_{4}\right], \mathrm{C}_{32} \mathrm{H}_{28} \mathrm{O}_{8} \mathrm{BrRu}_{2}$ : C, 46.72; H, 3.43. Found (\%): C, 47.02; H, 3.42.

IR $\left(\mathrm{cm}^{-1}\right): 2920 \mathrm{w}, 1591 \mathrm{w}, 1508 \mathrm{~m}, 1493 \mathrm{~m}, 1466 \mathrm{~m}, 1413 \mathrm{~s}, 1386 \mathrm{~s}, 1288 \mathrm{~m}, 1225 \mathrm{~m}, 1168 \mathrm{w}, 1120 \mathrm{w}$, 1089m, 1040w, 1006w, 932w, 912w, 898w, 816w, 791m, 748s, 679s.

$$
\mu_{\mathrm{eff}}(\mathrm{rt})=4.50 \mu_{\mathrm{B}} \text {. }
$$

Synthesis of $\left[\mathrm{Ru}_{2} \mathrm{Br}\left(\mu-\mathrm{O}_{2} \mathrm{CC}_{6} \mathrm{H}_{4}-p-\mathrm{Me}\right)_{4}\right]$, 3. This compound was obtained using the same synthetic methods described for 1 , with $m$-toluic acid ( $0.20 \mathrm{~g}, 1.5 \mathrm{mmol})$.

Method (a): Yield: 51\%. Anal. Calcd. (\%) for $\left[\mathrm{Ru}_{2} \mathrm{Br}\left(\mu-\mathrm{O}_{2} \mathrm{CC}_{6} \mathrm{H}_{4}-p-\mathrm{Me}\right)_{4}\right], \mathrm{C}_{32} \mathrm{H}_{28} \mathrm{O}_{8} \mathrm{BrRu}_{2}$ : C, 46.72; H, 3.43. Found (\%): C, 46.63; H, 3.44.

Method (b): Yield: $65 \%$. Anal. Calcd. (\%) for $\left[\mathrm{Ru}_{2} \mathrm{Br}\left(\mu-\mathrm{O}_{2} \mathrm{CC}_{6} \mathrm{H}_{4}-p-\mathrm{Me}\right)_{4}\right] \cdot 0.5 \mathrm{H}_{2} \mathrm{O}, \mathrm{C}_{32} \mathrm{H}_{29} \mathrm{O}_{8.5} \mathrm{BrRu}_{2}$ : C, 46.22; H, 3.51. Found (\%): C, 46.13; H, 3.38.

Method (c): Yield: $89 \%$. Anal. Calcd. (\%) for $\left[\mathrm{Ru}_{2} \mathrm{Br}\left(\mu-\mathrm{O}_{2} \mathrm{CC}_{6} \mathrm{H}_{4}-p-\mathrm{Me}\right)_{4}\right] \cdot 0.5 \mathrm{H}_{2} \mathrm{O}, \mathrm{C}_{32} \mathrm{H}_{29} \mathrm{O}_{8.5} \mathrm{BrRu}_{2}$ : C, 46.22; H, 3.51. Found (\%): C, 46.02; H, 3.37.

IR $\left(\mathrm{cm}^{-1}\right): 2916 \mathrm{w}, 1607 \mathrm{~m}, 1514 \mathrm{w}, 1448 \mathrm{~m}, 1398 \mathrm{~s}, 1296 \mathrm{~m}, 1212 \mathrm{w}, 1179 \mathrm{~m}, 1145 \mathrm{~m}, 1116 \mathrm{w}, 1121 \mathrm{w}$, $854 \mathrm{w}, 843 \mathrm{w}, 781 \mathrm{~m}, 753 \mathrm{~s}, 693 \mathrm{~m}$.

$$
\mu_{\mathrm{eff}}(\mathrm{rt})=4.20 \mu_{\mathrm{B}} \text {. }
$$

\section{Conclusions}

Bromidotetraarylcarboxyatodiruthenium(II,III) complexes can be obtained using microwave activation with moderate to high yield. Solvothermal activation and conventional synthesis lead to the same complexes in similar yields. No appreciable differences have been observed in the properties of the compounds depending on the synthetic procedure. The presence of a methyl substituent in the ortho, metha or para positions does not have any significant influence on the properties of these complexes. The change of chloride ion by bromide ligand as a connector between the dinuclear units has little influence on the properties of the halidotetracarboxylatodiruthenium compounds. 


\section{Acknowledgments}

Financial support received from the Ministerio de Economía y Competitividad (MEC) (CTQ2011-23066) and Comunidad de Madrid (S2009/MAT-1467) is gratefully acknowledged.

\section{Author Contributions}

Patricia Delgado-Martínez: Performed most of the experimental work, spectroscopic data and powder X-ray data; Alejandra Elvira-Bravo: Performed some part of the experimental work; Rodrigo González-Prieto: Performed some of the spectroscopic data and magnetic data; José L. Priego: Assisted with experimental procedures and design of the experiments; Reyes Jimenez-Aparicio: Provided full research assistance and supervised the research; M. Rosario Torres: Performed X-ray data and solved the X-ray structures. The results were discussed by all the authors. The preparation of the manuscript is made by all the authors (except Alejandra Elvira-Bravo).

\section{Conflicts of Interest}

The authors declare no conflict of interest.

\section{References}

1. Cotton, F.A.; Curtis, N.F.; Harris, C.B.; Johnson, B.F.G.; Lippard, S.J.; Mague, J.T.; Robinson, W.R.; Wood, J.S. Mononuclear and polynuclear chemistry of rhenium(III): Its pronounced homophilicity. Science 1964, 145, 1305-1307.

2. Cotton, F.A.; Walton, R.A. Multiple Bonds between Metal Atoms, 2nd ed.; Wiley: New York, NY, USA, 1993.

3. Cotton, F.A.; Murillo, C.; Walton, R.A. Multiple Bonds between Metal Atoms, 3rd ed.; Springer: New York, NY, USA, 2005.

4. Aquino, M.A.S. Diruthenium and diosmiumtetracarboxylates: Synthesis, physical properties and applications. Coord. Chem. Rev. 1998, 170, 141-202.

5. Aquino, M.A.S. Recent developments in the synthesis and properties of dirutheniumtetracarboxylates. Coord. Chem. Rev. 2004, 248, 1025-1045.

6. Norman, J.G.; Renzoni, E.; Case, D.A. Electronic structure of $\mathrm{Ru}_{2}\left(\mathrm{O}_{2} \mathrm{CR}\right)_{4}{ }^{+}$and $\mathrm{Rh}_{2}\left(\mathrm{O}_{2} \mathrm{CR}\right)_{4}{ }^{+}$ complexes. J. Am. Chem. Soc. 1979, 101, 5256-5267.

7. Messori, M.; Marzo, T.; Fernandes Sanches, R.N.; Hanif-Ur-Rehman; de Oliveira Silva, D.; Merlino, A. Unusual Structural Features in the Lysozyme Derivative of the Tetrakis(acetato)chloridodiruthenium(II,III) Complex. Angew. Chem. Int. Ed. 2014, 53, 6172-6175.

8. Miyake, J.A.; Benadiba, M.; Ribeiro, G.; Silva, D.D.; Colquhoun, A. Novel RutheniumGamma-linolenic Acid Complex Inhibits C6 Rat Glioma Cell Proliferation in Vitro and in the Orthotopic C6 Model in Vivo after Osmotic Pump Infusion. Anticancer Res. 2014, 34, 1901-1911. 
9. Cummings, S.P.; Savchenko, J.; Fanwick, P.E.; Kharlamova, A.; Ren, T. Diruthenium Alkynyl Compounds with Phosphonate Capping Groups. Organometallics 2013, 32, 1129-1132.

10. Kuwahara, R.; Fujikawa, S.; Kuroiwa, K.; Kimizuka, N. Controlled Polymerization and Self-Assembly of Halogen-Bridged Diruthenium Complexes in Organic Media and Their Dielectrophoretic Alignment. J. Am. Chem. Soc. 2012, 134, 1192-1199.

11. Welte, L.; González-Prieto, R.; Olea, D.; Torres, M.R.; Priego, J.L.; Jiménez-Aparicio, R.; Gómez-Herrero, J.; Zamora, F. Time-Dependence Structures of Coordination Network Wires in Solution. ACS Nano 2008, 2, 2051-2056.

12. Olea, D.; González-Prieto, R.; Priego, J.L.; Barral, M.C.; de Pablo, P.J.; Torres, M.R.; Gómez-Herrero, J.; Jiménez-Aparicio, R.; Zamora, F. MMX polymer chains on surfaces. Chem. Commun. 2007, 1591-1593.

13. Blum, A.S.; Ren, T.; Parish, D.A.; Trammell, S.A.; Moore, M.H.; Kushmerick, J.G.; Xu, G.-L.; Deschamps, J.R.; Pollack, S.K.; Shashidhar, R. Ru $2(a p)_{4}(\sigma-o l i g o($ phenyleneethynyl)) Molecular Wires: Synthesis and Electronic Characterization. J. Am. Chem. Soc. 2005, 127, 10010-10011.

14. Johnson, K.D.; Powell, G.L. Microwave-assisted synthesis of dimolybdenumtetracarboxylates and a decanuclear osmium cluster. J. Organomet. Chem. 2008, 693, 1712-1715.

15. Herrero, S.; Jiménez-Aparicio, R.; Perles, J.; Priego, J.L.; Urbanos, F.A. First microwave synthesis of multiple metal-metal bond paddlewheel compounds. Green Chem. 2010, 12, 965-967.

16. Herrero, S.; Jiménez-Aparicio, R.; Perles, J.; Priego, J.L.; Saguar, S.; Urbanos, F.A. Microwave methods for the synthesis of paddlewheel diruthenium compounds with $N, N$-donor ligands. Green Chem. 2011, 13, 1885-1890.

17. Delgado, P.; González-Prieto, R.; Jiménez-Aparicio, R.; Perles, J.; Priego, J.L.; Torres, M.R. Comparative study of different methods for the preparation of tetraamidato and tetracarboxylatodiruthenium compounds. Structural and magnetic characterization. Dalton Trans. 2012, 41, 11866-11874.

18. Delgado-Martínez, P.; Gómez-García, C.J.; González-Prieto, R.; Jiménez-Aparicio, R.; Priego, J.L.; Torres, M.R. Structural, magnetic and electrical properties of one-dimensional tetraamidatodiruthenium compounds. 2014, 43, 3227-3237.

19. Cortijo, M.; Herrero, S.; Jiménez-Aparicio, R.; Matesanz, E. Modulation of the Magnetic Properties of Two-Dimensional Compounds $\left[\mathrm{NiX}_{2}(\mathrm{~N}-\mathrm{N})\right]$ by Tailoring Their Crystal Structure. Inorg. Chem. 2013, 52, 7087-7093.

20. Cortijo, M.; Herrero, S.; Jiménez-Aparicio, R.; Perles, J.; Priego, J.L.; Torralvo, M.J.; Torroba, J. Hybrid Polyfunctional Systems Based on Nickel(II) Isonicotinate. Eur. J. Inorg. Chem. 2013, 2580-2590.

21. Cortijo, M.; Herrero, S.; Jiménez-Aparicio, R.; Perles, J.; Priego, J.L.; Torroba, J. Tuning of Adsorption and Magnetic Properties in a Series of Self-Templated Isostructural Ni(II) Metal-Organic Frameworks. Cryst. Growth Des. 2014, 14, 716-722.

22. Cortijo, M.; Herrero, S.; Jerez, B.; Jiménez-Aparicio, R.; Perles, J.; Priego, J.L.; Torroba, J.; Tortajada, J. One-Dimensional $\left[\mathrm{Ni}\left(\mathrm{O}_{2} \mathrm{CR}\right)_{2}(\mathrm{~N}-\mathrm{N})_{x}\right]$ Polymers: Structural, Magnetic, and Density Functional Theory Studies. ChemPlusChem 2014, 79, 951-961. 
23. Kimura, T.; Sakurai, T.; Shima, M.; Togano, T.; Mukaida, M.; Nomura, T. Structure of Tetra- $\mu$-formatodiruthenium Bromide. Bull. Chem. Soc. Jpn. 1982, 55, 3927-3928.

24. Barral, M.C.; González-Prieto, R.; Jiménez-Aparicio, R.; Priego, J.L.; Torres, M.R.; Urbanos, F.A. Synthesis, Properties, and Structural Characterization of Bromo- and Iodotetracarboxylatodiruthenium(II,III) Compounds. Eur. J. Inorg. Chem. 2004, 4491-4501.

25. Miskowski, V.M.; Hopkins, M.D.; Winkler, J.R.; Gray, H.B. Multiple Metal-Metal Bonds. In Inorganic Electronic Structure and Spectroscopy, Volume II: Applications and Case Studies; Solomon, E.I., Lever, A.B.P., Eds.; John Wiley and Sons: New York, NY, USA, 1999; pp. 343-402.

26. Miskowski, V.M.; Gray, H.B. Electronic spectra of $\mathrm{Ru}_{2}$ (carboxylate) ${ }_{4}{ }^{+}$complexes. Higher energy electronic excited states. Inorg. Chem. 1988, 27, 2501-2506.

27. Miskowski, V.M.; Loehr, T.M.; Gray, H.B. Electronic and vibrational spectra of $\mathrm{Ru}_{2}$ (carboxylate) ${ }_{4}^{+}$complexes. Characterization of a high-spin metal-metal ground state. Inorg. Chem. 1987, 26, 1098-1108.

28. Clark, R.J.H.; Franks, M.L. Resonance Raman spectra of chlorotetra-acetatoand chlorotetrabutyrato-diruthenium. Dalton Trans. 1976, 1825-1828.

29. Clark, R.J.H.; Ferris, L.T.H. Resonance Raman, excitation profile and electronic structural studies of diruthenium tetracarboxylate complexes. Inorg. Chem. 1981, 20, 2759-2766.

30. Castro, A.M.; Roitberg, A.E.; Cukiernik, F.D. Theoretical and Experimental Studies of Diruthenium Tetracarboxylates Structure, Spectroscopy, and Electrochemistry. Inorg. Chem. 2008, 47, 4682-4690.

31. Cukiernik, F.D.; Luneau, D.; Marchon, J.-C.; Maldivi, P. Mixed-Valent Diruthenium Long-Chain Carboxylates. 2. Magnetic Properties. Inorg. Chem. 1998, 37, 3698-3704.

32. Mikuriya, M.; Yoshioka, D.; Handa, M. Magnetic interactions in one-, two-, and three-dimensional assemblies of dinuclear ruthenium carboxylates. Coord. Chem. Rev. 2006, 250, 2194-2211.

33. Estiú, G.; Cukiernik, F.D.; Maldivi, P.; Poizat, O. Electronic, Magnetic, and Spectroscopic Properties of Binuclear DirutheniumTetracarboxylates: A Theoretical and Experimental Study. Inorg. Chem. 1999, 38, 3030-3039.

34. Mitchell, R.W.; Spencer, A.; Wilkinson, G. Carboxylato-triphenylphosphine Complexes of Ruthenium, Cationic Triphenylphosphine Complexes derived from them, and their Behaviour as Homogeneous Hydrogenation Catalysts for Alkenes. Dalton Trans. 1973, 846-854.

35. Mukaida, M.; Nomura, T.; Ishimori, T. Synthesis of Formato-, Acetato-, Benzoato-, and Chlorosubstituted Acetatoruthenium Complexes, and their Properties. Bull. Chem. Soc. Jpn. 1972, $45,2143-2147$.

36. Sheldrick, G.M. A short history of SHELX. Acta Crystallogr. Sect. A 2008, 64, 112-122.

37. The Cambridge Crystallographic Data Centre. Available online: www.ccdc.cam.ac.uk/ data_request/ci (accessed on 3 July 2014).

(C) 2014 by the authors; licensee MDPI, Basel, Switzerland. This article is an open access article distributed under the terms and conditions of the Creative Commons Attribution license (http://creativecommons.org/licenses/by/3.0/). 